\title{
PENERAPAN TEKNOLOGI DALAM KERANGKA PENINGKATAN PRODUKTIVITAS USAHATANI TERNAK
}

\author{
Obed Haba Nono*, Petrus Kune*, Agust R. Riwu * dan Kristomus Boimau** \\ * Program Studi Ilmu Peternakan Fakultas Peternakan, Universitas Nusa Cendana Kupang. \\ ** Program Studi Teknik Mesin Fakultas Sains dan Teknik, Universitas Nusa Cendana Kupang. \\ e-mail: obedhaba@gmail.com
}

\begin{abstract}
ABSTRAK
Tujuan dari kegiatan ini adalah untuk: 1) meningkatkan keterampilan mitra dalam menggunakan sejumlah teknologi tepat guna, 2) meningkatkan produktivitas aneka usaha. Hal ini sesuai dengan karakteristik masalah yang dihadapi mitra, yaitu : manajemen produksi yang mengacu kepada optimalisasi sumber daya untuk peningkatan produktivitas, terbatasnya peralatan produksi dan aspek sosial ekonomi yang dialami oleh dua kelompok tani ternak yaitu Dahulu Rasa dan Tunas Baru. Metode yang diterapkan adalah : (1) penentuan mitra dan ilmu Pengetahuan Teknologi dan seni (IPTEKS) yang diterapkan adalah observasi, wawancara mendalam sehingga penentuan mitra dilakukan secara purposive. (2) metode dalam aplikasi IPTEKS berupa pelatihan, uji demoplot serta pendampingan. Demplot berupa aplikasi dari sejumlah teknologi yaitu : (a) teknologi intensifikasi padi aerob terkendali berbasis organik (IPAT-BO) untuk tanaman padi, (b) mesin tetas, (c) pembuatan reaktor / aplikasi biogas, dan (5) pembuatan serta aplikasi pupuk organik berbahan baku lokal.

Hasil kegiatan berupa sejumlah produk meliputi : gabah, ternak ayam/babi bermutu, pupuk organik (padat dan cair) hasil aplikasinya: aneka sayur -mayur. Hasil biogas berupa :gas untuk memasak, pupuk organik (padat dan cair), kangkung serta aneka sayuran organik. Kesimpulan : bentuk/jenis IPTEKS berupa sejumlah teknologi tepat guna berdampak kepada : (1) hasil IPAT-BO sanggup meningkatkan produktivtas gabah sebesar 54,67 persen, efisiensi benih dan air sebesar 300\% (2) efisiensi waktu dan produktivitas dan mutu ayam meningkat (3-3,5 kali lipat); (3) Produksi meningkat dan efisiensi input/waktu untuk sayur organic (25-50\%) dan (4)
\end{abstract}


Efisiensi biaya penggunaan BBM dapat mencapai Rp. 8,76 juta per tahun dari 2 buah kompor dari sebuah reaktor biogas.

Kata kunci : teknologi, IPAT-BO, biogas, pupuk organik, mesin tetas.

\section{PENDAHULUAN}

Sejumlah karakteristik dari usaha mikro, kecil dan menengah adalah 1) permasalahan keterbatasan modal, 2) manajemen produksi dan pemasaran, (wibowo dkk., 1988). Permsalahan ini berkaitan dengan kapasitas sumber daya manusia (SDM) yang dimiliki, termasuk tingkat teknologi yang dimiliki. Oleh karena itu injeksi teknologi sesuai dengan kapasitas SDM dan permintaan produk merupakan alternatif kunci dalam kerangka peningkatan produktivitas semua cabang usaha yang dimiliki mitra (usaha mikro-red).

Mitra dalam kegiatan program kemitraan masyarakat (PKM) ini adalah 2 kelompok tani ternak yang ada di Desa Mata Air yaitu Dahulu Rasa dan Tunas Baru. Desa Mata Air merupakan salah satu wilayah di Kecamatan Kupang Tengah Kabupaten Kupang sebagai sentra produksi padi, sayuran dan aneka ternak. Target utama pasar kota kupang sebagai pasar terbesar di NTT. Wilayah yang memiliki potensi sangat besar. Hal ini di dukung oleh ketersediaan air, fasilitas infrastuktur yang cukup baik, seperti jalan negara, fasilitas transportasi (angkutan umum roda empat dan dua / ojek) listrik dan komunikasi serta jarak wilayah tersebut sekitar 3-7 km dari Kota Kupang sebagai ibukota provinsi. Penentuan mitra didasarkan pada hasil diskusi mendalam, observasi serta kesekapatan dalam penentuan jenis teknologi dan penataan usaha berdasarkan masalah krusial / struktural yang dihadapi mtra

\section{MASALAH}

Berdasarkan analisis situasi serta hasil diskusi intens dengan pengurus / anggota kelompok, PPL dan aparat di wilayah tersebut, ditemukan masalah umum yaitu masih rendahnya keterampilan mitra dalam hal penguasaan teknologi yang menjamin integrasi antar cabang usaha serta yang ramah lingkungan. Hasil perumusan selanjutnya ditemukan 2 masalah khusus yaitu : 
(1) Permasalahan produksi meliputi : (a) Produktivitas padi sawah masih rendah akibat sistem produksi sederhana yang ditunjukkan, masih borosnya penggunaan input terutama : air, benih dan pupuk; (b) Produksi dan produktivitas aneka usaha ternak masih rendah. Hal ini disebabkan oleh sistem produksi yang ekstensif tradisional. Keekstensifan ini berkaitan erat dengan penguasaan ilmu pengetahuan dan teknologi produksi, dan atau pengolahan limbah yang masih rendah sehingga belum memberikan manfaat optimal kepada usahatani lainnya melalui prinsip integrasi; (d). Untuk ternak babi, penguasaan teknologi reproduksi dan manfaat kawin suntik nyaris belum ada, sehingga umumnya cenderung inbreeding, pengolahan limbah serta pengetahuan tentang pengendalian kesehatan ternak (termasuk dalam usaha ternak sapi) masih rendah; (e).Untuk usaha ternak ayam buras produktivitas masih rendah, karna pemilihan bibit, perkandangan masih sederhana, sistem reproduksi masih dierami induk sehingga siklus produksi hanya 3-4 kali per tahun.

(2) Permasalahan manajemen usaha meliputi: (a) Perencanaan usaha meliputi penentuan skala usaha, perencanaan produksi, dan pemasaran masih sederhana sehingga tidak mampu merespon permintaan pasar yang amat besar; (b). Aspek sumber daya manusia, yaitu belum ada tenaga teknis yang dapat mendampingi kelompok tersebut dalam menerapkan teknologi IPAT-BO yang mampu meningkatkan produktivitas usaha pertanian (terutama padi sawah), teknologi biogas dalam pemanfataan limbah kandang (terutama dari aneka usaha ternak seperti sapi, babi dan kambing) dimana limbahnya dapat dijadikan pupuk cair untuk aneka sayuran dan palawija, penanganan kesehatan ternak dan peternakan (terutama ternak babi dan ayam buras) serta teknologi peningkatan produksi dan produktivitas dari ayam buras melalui aplikasi mesin tetas.

Berdasarkan uraian di atas, tujuan kegiatan tersebut adalah untuk meningkatkan:

(1) keterampilan mitra dalam budidaya, pengolahan limbah serta berusaha tani yang ramah lingkungan, (2) produksi / produktivitas atau efisiensi usaha terutama untuk padi sawah, aneka hortikultura berupa sayuran dan buah-buahan, ternak ayam buras dan ternak babi. 


\section{METODE PELAKSANAAN}

Kegiatan PKM dilaksanakan pada 2 mitra sejak bulan Maret sampai dengan Oktober 2017, dengan durasi kegiatan \pm 8 bulan. Adapun tahapan kegiatan meliputi tahapan persiapan dan pelaksanaan. Tahapan persiapan meliputi : penentuan mitra, kesepakatan tentang teknologi (alat dan bahan yang dibutuhkan), waktu pelaksanaan berdasarkan jenis kegiatan.

\section{1). Tahap persiapan}

a) Penentuan responden / mitra.- Adapun metode pelaksanaan kegiatan dimulai dari penentuan reponden sampai dengan penerapan IPTEKS. Pada penentuan responden (mitra) didasarkan kepada sejumlah observasi, diskusi mendalam terhadap sejumlah pihak seperti aparat (terutama Kades, PPL, tokoh masyarakat lainnya) sebagai narasumber. Penentuan mitra setelah diskusi / wawancara mendalam dengan sejumlah kelompok tani ternak akhirnya ditentukan mitra berupa 2 kelompok tani ternak, yaitu : Kelompok Tani Dahulu Rasa dan Kelompok Tani Tunas Baru serta masyarakat peternak di desa tersebut serta penentuan lokasi dan tempat demplot IPTEKS yang akan diaplikasikan.

b) Bahan dan alat yang digunakan dan Produktivitas Hasil Penerapan. Adapun bahan dan alat yang dibutuhkan / digunakan dalam setiap IPTEKS mulai dari pembuatan sampai dengan penerapannya tertera pada Tabel 1.

Tabel 1. Jenis IPTEKS, alat dan bahan, spesifikasi dan produktivitas IPTEKS

\begin{tabular}{|c|l|l|l|l|l|}
\hline No & \multicolumn{1}{|c|}{$\begin{array}{c}\text { Jenis } \\
\text { IPTEKS }\end{array}$} & $\begin{array}{c}\text { Alat dan Bahan } \\
\text { yang Digunakan }\end{array}$ & $\begin{array}{c}\text { Spesifikasi } \\
\text { Alat }\end{array}$ & $\begin{array}{c}\text { Cara } \\
\text { mengukurnya }\end{array}$ & \multicolumn{1}{c|}{ Produktivitasnya } \\
\hline 1 & IPAT-BO & $\begin{array}{l}\text { Pacul, alat } \\
\text { penyiangan, benih }\end{array}$ & $\begin{array}{l}\text { Sesuai } \\
\text { kebutuhan, } \\
\text { untuk 20 are } \\
\text { hanya 3kg } \\
\text { benih }\end{array}$ & $\begin{array}{l}\text { Pencatatan } \\
\text { setelah } \\
\text { perlakuan, } \\
\text { mulai tanam s/d } \\
\text { panen, }\end{array}$ & $\begin{array}{l}\text { Ada efisiensi benih sebesar } \\
300 \% \text { dan air 300\%, produk } \\
\text { tivitas } \\
\text { meningkat } \\
\text { sebesar } \\
\text { menjadi 6,96 ton per ha. }\end{array}$ \\
\hline 2 & Mesin tetas & $\begin{array}{l}\text { Triplex, kayu usuk, } \\
\text { thermostat, } \\
\text { termometer, kaca, } \\
\text { sekam padi (untuk } \\
\text { alas dinding mesin) }\end{array}$ & $\begin{array}{l}\text { 2 Kapasitas } \\
100 \text { butir }\end{array}$ & $\begin{array}{l}\text { Pencatatan } \\
\text { setiap telur yang } \\
\text { ditetaskan }\end{array}$ & $\begin{array}{l}\text { Efsiensi waktu sebesar 300\%, } \\
\text { produksi anak atau } \\
\text { peningkatan } \\
\text { populasi sebesar 3x, mutu } \\
\text { ayam lebih baik }\end{array}$ \\
\hline 3 & $\begin{array}{l}\text { Reaktor } \\
\text { biogas }\end{array}$ & $\begin{array}{l}\text { Fiber, alat las, } \\
\text { selang, kran, } \\
\text { kompor, kotoran } \\
\text { sapi, babi }\end{array}$ & $\begin{array}{l}\text { Kapasitas } \\
1200 \text { liter }\end{array}$ & $\begin{array}{l}\text { Berdasarkan } \\
\text { kelancaran } \\
\text { pemanfaatan } \\
\text { gas }\end{array}$ & $\begin{array}{l}\text { Gas cukup untuk memasak } \\
\text { dari 2 rumah tangga }\end{array}$ \\
\hline
\end{tabular}




\begin{tabular}{|c|l|l|l|l|l|}
\hline No & \multicolumn{1}{|c|}{$\begin{array}{c}\text { Jenis } \\
\text { IPTEKS }\end{array}$} & $\begin{array}{c}\text { Alat dan Bahan } \\
\text { yang Digunakan }\end{array}$ & $\begin{array}{c}\text { Spesifikasi } \\
\text { Alat }\end{array}$ & $\begin{array}{c}\text { Cara } \\
\text { mengukurnya }\end{array}$ & \multicolumn{1}{c|}{ Produktivitasnya } \\
\hline 4 & $\begin{array}{l}\text { Pupuk } \\
\text { organik/ } \\
\text { bokashi }\end{array}$ & $\begin{array}{l}\text { Limbah kandang } \\
\text { ternak (babi, sapi, } \\
\text { ayam potong), } \\
\text { EM4, gula pasir/air, } \\
\text { ember, terpal, } \\
\text { sekop, karung }\end{array}$ & $\begin{array}{l}\text { Kapasitas } \\
500-1000 \mathrm{~kg}\end{array}$ & $\begin{array}{l}\text { Pengukuran } \\
\text { terhadap berat, } \\
\text { dan interval } \\
\text { waktu panen } \\
\text { dari kangkung, } \\
\text { dan aneka } \\
\text { sayuran lainnya }\end{array}$ & $\begin{array}{l}\text { Produktivitas lebih tinggi } \\
\text { sebesar 50\%, efisiensi waktu } \\
\text { sebesar 25-50\%, sedangkan } \\
\text { jeruk nipis menghasilkan } \\
\text { sepanjang tahun }\end{array}$ \\
\hline 5 & $\begin{array}{l}\text { Kesehatan } \\
\text { ternak }\end{array}$ & $\begin{array}{l}\text { Obat, vitamin dan } \\
\text { alat suntik }\end{array}$ & $\begin{array}{l}\text { Sesuai } \\
\text { kebutuhan }\end{array}$ & $\begin{array}{l}\text { Berdasarkan } \\
\text { dosis dari setiap } \\
\text { jenis tindakan } \\
\text { (preventif dan } \\
\text { kuratif) }\end{array}$ & Ternak babi lebih sehat \\
\hline
\end{tabular}

\section{2) Tahap Pelaksanaan}

Dalam membantu kelompok dan masyarakat petani peternak (mitra) melalui : pelatihan, demplot, pendampingan dan promosi. Adapun kegiatan yang sudah dilaksanakan adalah sebagai berikut :

a. Pelatihan disampaikan dalam bentuk ceramah dan diskusi, dengan sejumlah materi oleh tim pelaksana, sejumlah 21 orang peserta, ditambah dengan masyarakat sehamparan dan mahasiswa atau alumni sehingga mencapai 38 orang yang dilakukan selama 4 hari. Yang menjadi sasaran kegiatan adalah anggota 2 Kelompok Tani (mitra), dan pemuda putus sekolah atau anggota masyarakat sehamparan dan lainnya.

b. Walaupun ada keterbatasan waktu / dana (pencairan sangat terlambat) untuk demplot IPAT-BO langsung pada lahan petani, namun cukup optimal.

c. Melakukan instalasi teknologi mesin tetas dan biogas dari fiber.

d. Demonstrasi (percontohan) pengolahan limbah ternak babi dan sapi (Biogas)

e. Memfasilitasi pembuatan / disain instalasi biogas.

f. Penerapan mesin penetasan telur yang memperlihatkan partisipasi sejumlah anggota dengan memasukkan telur dalam mesin tetas

g. Pembuatan pupuk organik yang diikuti oleh semua peserta

h. Kegiatan penanganan kesehatan ternak terutama ternak ayam atau babi

Selain itu, rancangan evaluasi terutama terhadap tingkat partisipasi, dan konsistensi mitra dan kelompok sehamparan dalam menerapkan atau memanfaatkan IPTEKS yang diinjeksikan. Secara diagramatik gambaran penerapan PKM tertera pada Gambar 1. 


\section{3) Cara Pengumpulan dan Analisis Data.}

Adapun cara pengumpulan data dan analisis data tertera pada Tabel 2.

Tabel 2. Cara pengumpulan dan analisis data berdasarkan IPTEKS yang diterapkan

\begin{tabular}{|c|c|c|c|c|}
\hline No & Uraian *) & Pengumpulan & Analisis & Keterangan Pengukuran \\
\hline 1 & IPAT-BO & $\begin{array}{l}\text { Pencatatan } \\
\text { perlakuan }\end{array} \begin{array}{r}\text { setiap } \\
\text { penalai } \\
\text { panen }\end{array}$ & $\begin{array}{lr}\text { Deskriptif } & \text { dan } \\
\text { inferensial, } & \text { rata2, } \\
\text { proksi bobot } & \end{array}$ & $\begin{array}{l}\text { Untuk tanaman padi dengan } \\
\text { penanaman benih tunggal } \\
\text { atau dua per lubang tanam }\end{array}$ \\
\hline 2 & Mesin Tetas & $\begin{array}{l}\text { Pencatatan jumlah telur } \\
\text { (ditetaskan, dan yang } \\
\text { menetas) }\end{array}$ & $\begin{array}{l}\text { \%penetasan }=\{\text { (telur } \\
\text { ditetaskan } \\
\text { menetas }) / \text { telur } \\
\text { ditetaskan }\} \times 100 \%\end{array}$ & $\begin{array}{l}\text { Tingkat penetasan bervairiasi } \\
\text { tergantung kefertilan dari } \\
\text { telur }\end{array}$ \\
\hline 3 & Pupuk organik & $\begin{array}{ll}\text { Pengukuran } & \text { bobot } \\
\text { bahan dan hasil } & \end{array}$ & Rata-rata & $\begin{array}{l}\text { Terutama dari pupuk padat, } \\
\text { sedangkan yang cair belum } \\
\text { sempat diukur secara rinci }\end{array}$ \\
\hline 4 & $\begin{array}{l}\text { Penanganan } \\
\text { Limbah } \\
\text { (Biogas) }\end{array}$ & $\begin{array}{l}\text { Pengukuran gas melalui } \\
\text { lama atau jangka waktu } \\
\text { masak }\end{array}$ & Rata-rata per minggu & $\begin{array}{lrr}\text { Belum } & \text { berjalan } & \text { stabil, } \\
\text { mungkin } & \text { karena } & \text { tingkat } \\
\text { kekentalan campuran } & \end{array}$ \\
\hline 5 & $\begin{array}{l}\text { Produksi aneka } \\
\text { sayuran }\end{array}$ & $\begin{array}{l}\text { Pengukuran interval } \\
\text { panen, bobot per satuan } \\
\text { luas (m2) }\end{array}$ & $\begin{array}{l}\text { Rata-rata = bobot } \\
\text { panen/Luas panen }\end{array}$ & $\begin{array}{l}\text { Untuk produksi tanaman } \\
\text { lainnya belum dihitung secara } \\
\text { rinci }\end{array}$ \\
\hline 6 & $\begin{array}{l}\text { Penanganan } \\
\text { penyakit ternak }\end{array}$ & $\begin{array}{l}\text { Pencatatan jenis dan } \\
\text { dosis obat berdasarkan } \\
\text { priode tumbuh ternak }\end{array}$ & - & $\begin{array}{l}\text { Jenis dan dosis obat serta } \\
\text { vitamin } \\
\text { kondisi/umur ternak babi }\end{array}$ \\
\hline
\end{tabular}

Catatan : *) Uraian efektifitas dan efisiensi IPTEKS

\section{4) Pendampingan, Monitoring dan Evaluasi}

Kegiatan tersebut bertujuan untuk memerikan dukungan langsung, bimbingan mapupun konsultasi teknis maupun manajemen usaha berkaitan dengan adopsi dan keberlanjtutan penerapan sejumlah teknologi yang diinjeksikan dalam kegiatan pelatihan / demplot.

\section{HASIL YANG DICAPAI}

\section{Hasil Kegiatan}

Tabel 3. Dampak / Hasil Kegiatan injeksi Teknologi berbasis integrasi usaha

\begin{tabular}{|c|c|c|c|c|c|c|}
\hline No & Teknologi & Uraian & Sebelum & Sesudah & Peningkatan & Keterangan \\
\hline \multirow[t]{3}{*}{1} & \multirow[t]{3}{*}{ IPAT-BO } & Produksi gabah & 4,5 ton $/ \mathrm{ha}$ & 6,96 ton per ha & $54,67 \%$ & \\
\hline & & Efisiensi benih & $40 \mathrm{~kg} / \mathrm{ha}$ & $7 \mathrm{~kg} / \mathrm{ha}$ & $300 \%$ & \\
\hline & & Efisiensi air & genangan & $\begin{array}{l}\text { Cukup atau } \\
\text { hanya becek }\end{array}$ & 3005 & \\
\hline
\end{tabular}




\begin{tabular}{|c|c|c|c|c|c|c|}
\hline No & Teknologi & Uraian & Sebelum & Sesudah & Peningkatan & Keterangan \\
\hline \multirow[t]{4}{*}{2} & \multirow[t]{4}{*}{$\begin{array}{l}\text { Pupuk } \\
\text { organik }\end{array}$} & $\begin{array}{l}\text { Efisiensi Produksi } \\
\text { sayuran } \\
\text {-produksi/hari }\end{array}$ & $40-50 \mathrm{~kg}$ & $80-120 \mathrm{~kg} /$ & $100-120 \%$ & $\begin{array}{l}\text { Sayuran tomat, } \\
\text { kangkung, sawi, } \\
\text { kol, terung dan } \\
\text { cabe serta jeruk } \\
\text { nipis, mangga }\end{array}$ \\
\hline & & -umur panen,hari & $32-35$ & $25-26$ & $20-25 \%$ & \\
\hline & & -efisiensi pupuk & Tidak & Tinggi & $40-50 \%$ & \\
\hline & & Ramah lingkungan & Tidak & Ramah & & $\begin{array}{l}\text { Termasuk aman } \\
\text { bagi kesehatan }\end{array}$ \\
\hline \multirow[t]{4}{*}{4} & \multirow[t]{4}{*}{ Mesin tetas } & Jenis ras ayam & lokal & Unggul & & \multirow{4}{*}{$\begin{array}{lr}\text { Kampung } & \text { diganti } \\
\text { Bangkok atau } \\
\text { turunan/sejenisnya }\end{array}$} \\
\hline & & Produksi anak/thn & $2-4 x$ & Setiap waktu & & \\
\hline & & Kandang anak & Tidak ada & ada & 2buah & \\
\hline & & Populasi ayam & Rendah & Cukup tinggi & $50 \%$ & \\
\hline \multirow[t]{2}{*}{5} & \multirow[t]{2}{*}{$\begin{array}{l}\text { Penanganan } \\
\text { Limbah } \\
\text { (Biogas) }\end{array}$} & $\begin{array}{l}\text { Pengukuran gas } \\
\text { melalui lama atau } \\
\text { jangka waktu masak }\end{array}$ & Tidak ada & Selalu tersedia & Tinggi & \\
\hline & & Efisiensi biaya $B B M$ & Tidak ada & tinggi & $\begin{array}{l}R p 8,76 \text { juta } \\
\text { pertahun }\end{array}$ & \\
\hline 6 & $\begin{array}{l}\text { Penanganan } \\
\text { kesehatan } \\
\text { ayam \& } \\
\text { Ternak babi } \\
\end{array}$ & $\begin{array}{l}\text { Penanganan } \\
\text { kesehtan } \\
\text { reproduksi }\end{array}$ & sederhana & Lebih baik & $20-40 \%$ & \\
\hline 7 & $\begin{array}{l}\text { Respon } \\
\text { mitra }\end{array}$ & Kehadiran & - & tinggi & $130 \%$ & Partisipasi aktif \\
\hline
\end{tabular}

\section{Gambaran tentang hasil kegiatan tertera pada Gambar 1.}

\section{Produk Pengabdian PKM bagi Mitra}

Teknologi IPAT-BO untuk tanaman padi,Pemanfataan Pupuk Limbah Kandang sapi dan babi milik mitra sebagai bahan baku pembuatan pupuk organic, instalasi reactor biogas, mesin tetas

Gabah hasil efisiensi benih, Pupuk organik, instalasi biogas (biogas sedang diproses), mesin tetas dan telur ayam buras yang diseleksi proses penetasan terus berjalan)

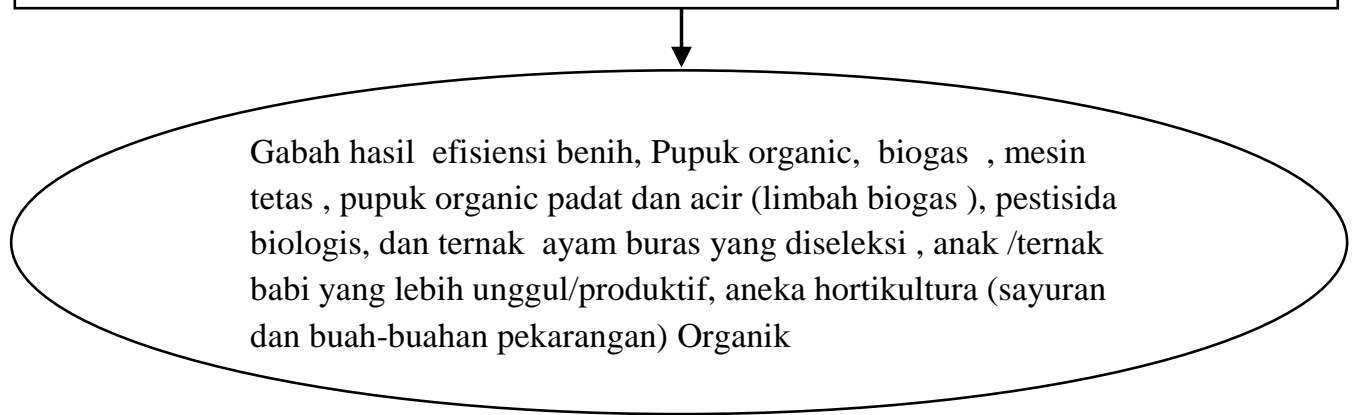

Gambar 1. Produk PKM Bagi Mitra 


\section{Adapun gambaran produk PKM sebagai berikut:}

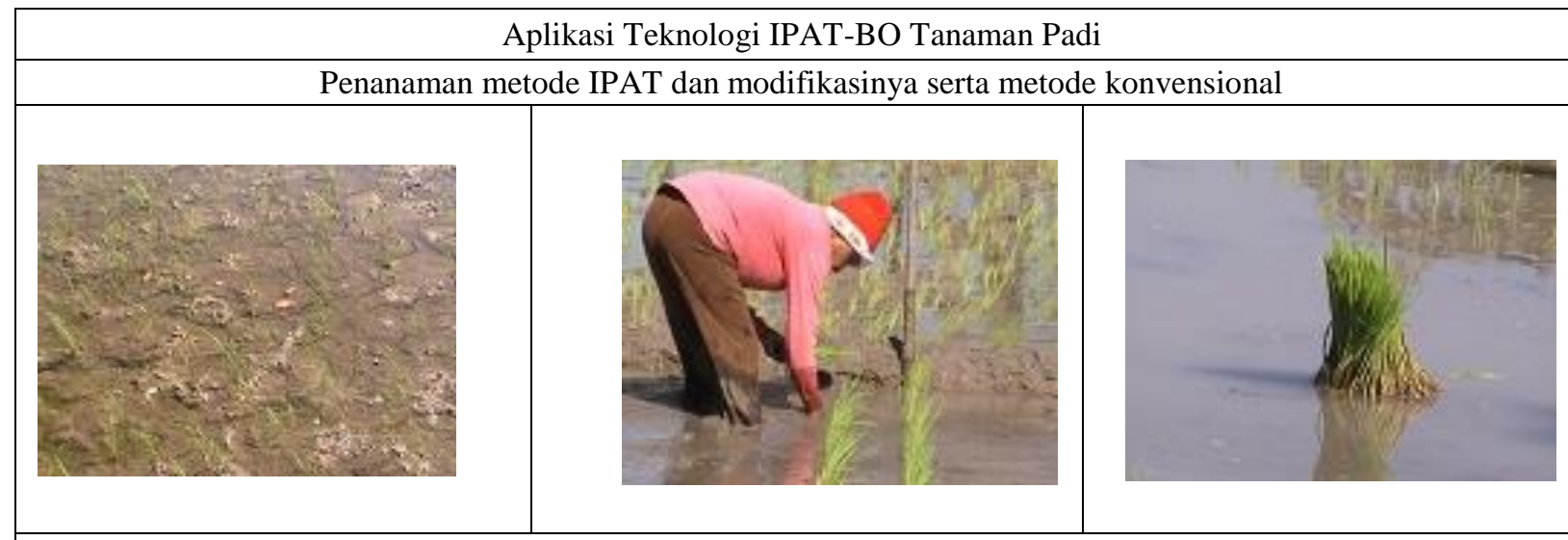

Ada efisiensi benih sebesar $300 \%$ dan air $300 \%$, produktivitas meningkat sebesar $54,67 \%$ dari rata-rata 4,5 ton menjadi 6,96ton per ha. Selain itu sebenarnya terdapat efisiensi waktu panen sebanyak 15-18 hari bila waktu penanaman umur benih 12-16 hari. Sedangkan metode konvensional umur benih saat dipindahkan dapat mencapai 28-35 hari

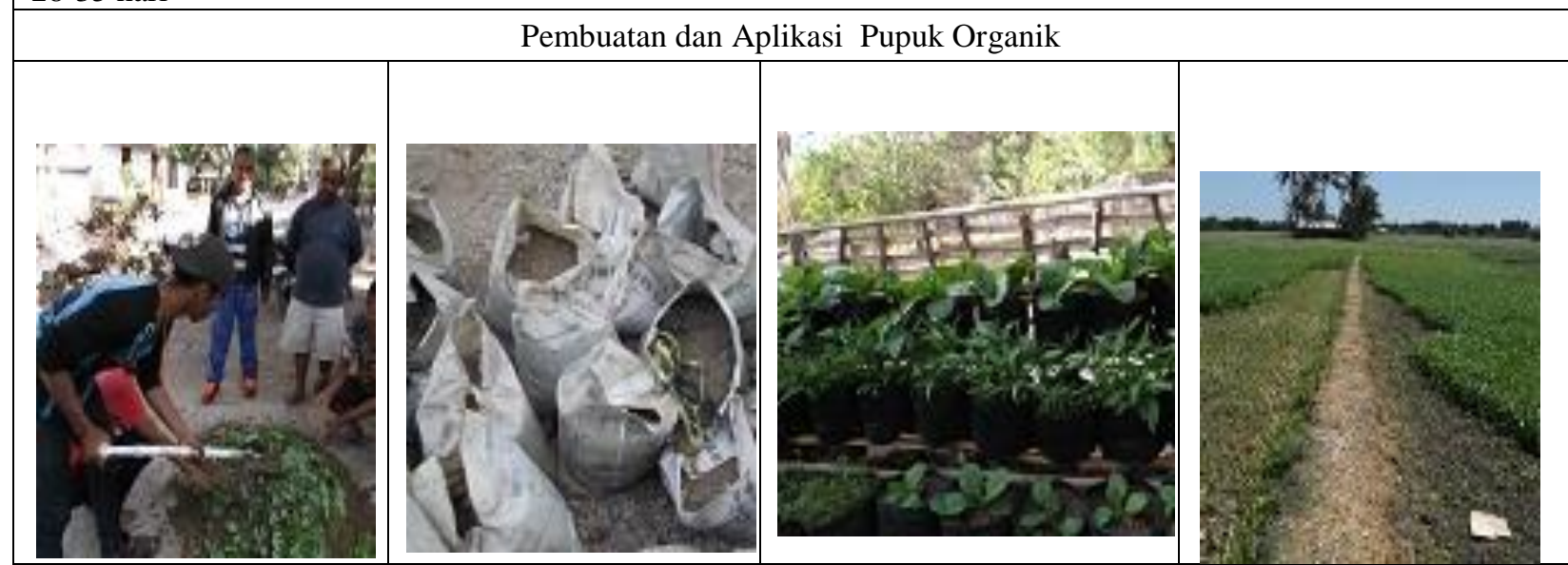

Produksi harian setiap hari mencapai 50-75 kg- diaplikasikan kepada kebun kangkung seluas 50 are, dan akan diperluas untuk kebun kangkung anggota lainnya. Hasilnya adalah efisiensi pupuk sebesar 100\% (tanpa gunakan pupuk kimia lagi); percepatan waktu panen sebanyak 5-7 hari, dari selang 3 minggu menjadi $2-2,5$ minggu; produktivitas meningkat sebesar 40-50\%; daya awet meningkat; Pangan lebih aman/sehat

Aplikasi Teknologi IPAT-BO Pupuk Organik

Produksi padi sebesar 6,96 ha meningkat dari rata-rata 4,5 ton /ha (atau meningkat sebesar 54,67\%), sedangkan untuk tanaman jeruk nipis menjadi berbuah selama kegiatan

Manfaat lainnya adalah usaha pertanian ini ramah lingkungan (prinsip integrasi), pangan yang dihasilkan lebih sehat karena organik 


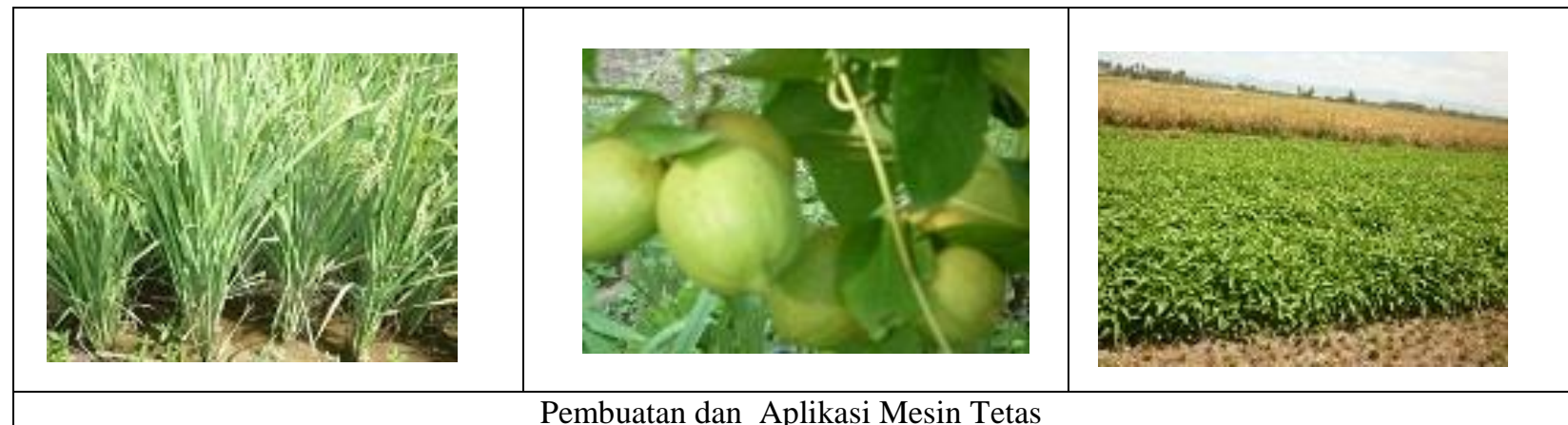

Pembuatan dan Aplikasi Mesin Tetas

Mesin dengan kapasitas 100 butir, populasi meningkat sebesar 60-300\%. Tergantung pemiliki telur yang memanfaatkan mesin tetas tersebut. Prinsip kebersamaan dapat lebih ditingkatkan dengan kesempatan memanfaatkan mesin oleh anggota kelompok dan masyarakat sekitarnya.

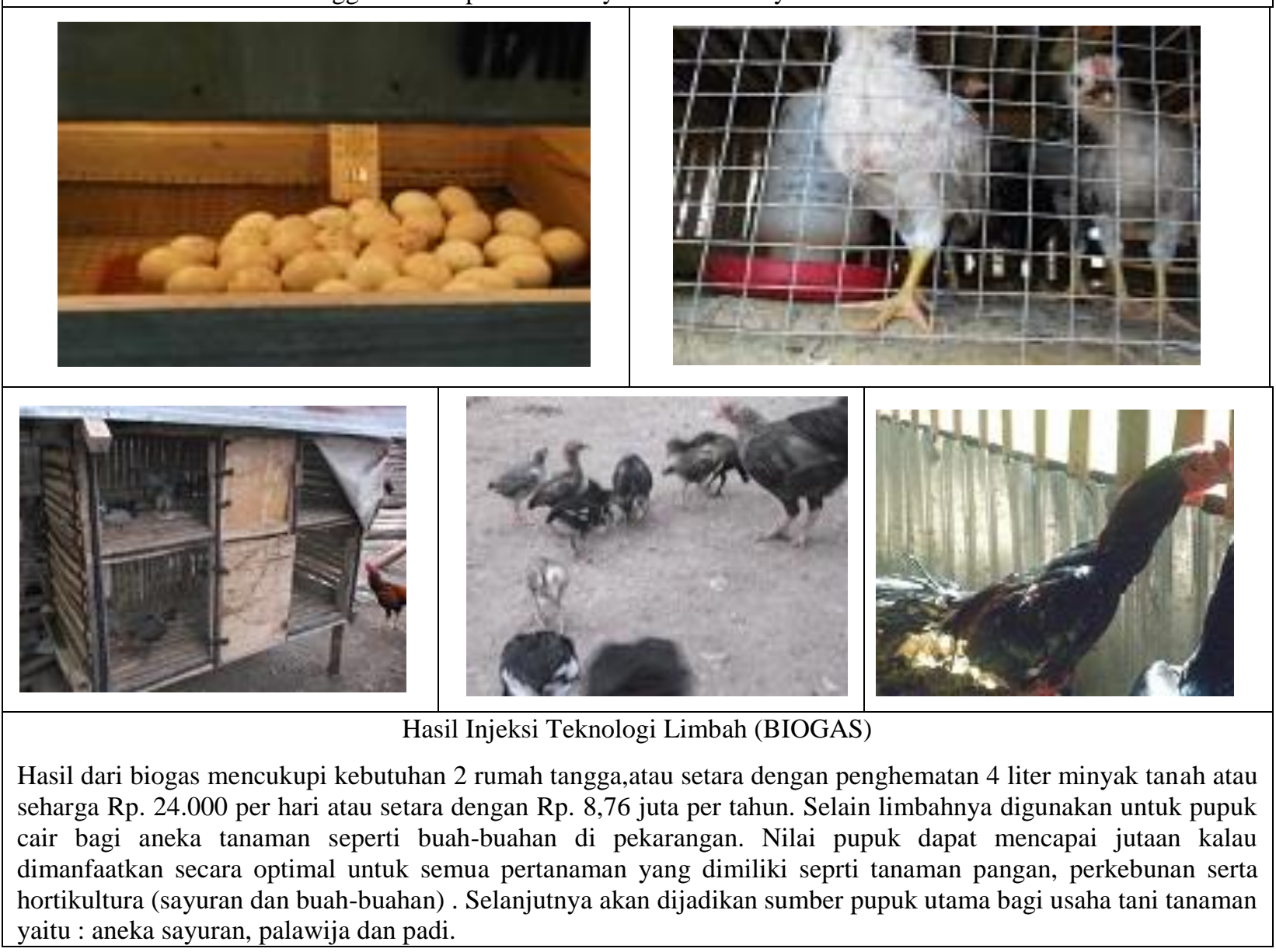




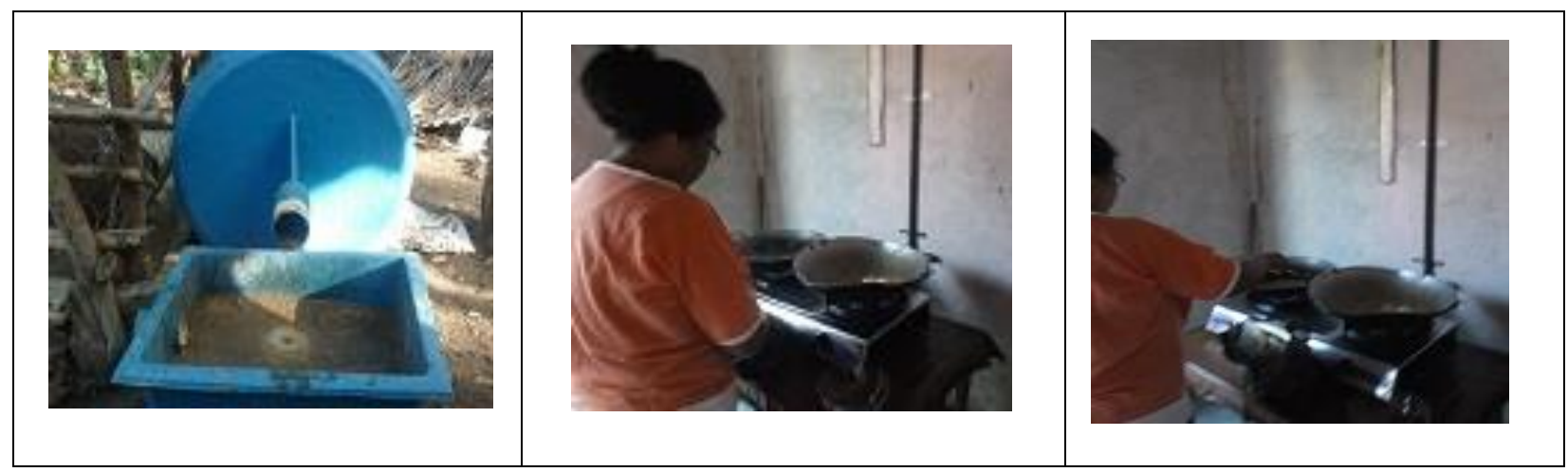

\section{Implikasi Temuan}

Berdasarkan dampak positif secara ekonomis dan non ekonomis di atas dan hasil pengamatan dan diskusi bersama mitra diperoleh gambaran bahwa;

1. Program Kemitraan Masyarakat (PKM) tentang penyuluhan, pendampingan dan pelatihan dapat meningkatkan pengetahuan dan keterampilan dalam berusaha. Dampak selanjutnya adalah peningkatan produksi / produktivitas usaha mereka serta dapat merespon permintaan pasar yang selalu meningkat.

2. Animo dan keaktifan peserta untuk berinovasi dalam aplikasi teknologi IPAT-BO, pengolahan limbah dan pemanfataannya lebih optimal/maksimal, ramah lingkungan dan berkelanjutan.

3. Masih diperlukan pendampingan untuk memfasilitasi mereka dalam berbagai hal demi kesinambungan dari peningkatan produktivitas usaha.

Hal ini sesuai dengan profil potret permasalahan lain yang terekam adalah:

1. Sumber Daya Manusia (SDM) dengan tingkat pendidikan yang relatif rendah dan penguasaan teknologi termasuk teknologi informasi yang masih terbatas;

2. Banyaknya cabang usaha yang diusahakan.

3. Masih sering terjadi wabah penyakit ternak termasuk di dalamnya: ternak babi dan ayam buras sehingga menjadi tantangan tersendiri bagi tim pelaksana dalam menfasilitasi mitra dan masyarakat sehamparan dan sekitarnya.

4. Perilaku petani dalam penggunaan pupuk dan obat kimiawi yang sudah berlangsung lama sudah mulai berubah . 
5. Belum adanya lembaga keuangan mikro untuk memfasilitasi mereka dalam berusaha tani terutama dari segi pendanaan untuk modal kerja.

Selain itu, pertanian organik sebagai salah satu target produk usahatani yang kompetitif ke depan dapat menjadi salah program kerja prioritas baik di desa Mata Air ataupun dari lembaga penelitian pengabdian kepada masyarakat (LPPM Undana) di semua wilayah (terutama di wilayah desa binaan) termasuk di wilayah Desa Mata Air Kecamatan Kupang Tengah Kabupaten Kupang.

\section{KESIMPULAN}

1. Hasil penerapan teknologi IPAT-BO sanggup meningkatkan produktivitas padi sebesar 54,67 persen, efisiensi benih dan air sebesar 300\%

2. Hasil penerapan teknologi mesin tetas memiliki efisiensi waktu produksi dan produktivitas mutu ayam meningkat (3-3,5 kali lipat).

3. Aplikasi pupuk organik meningkatkan produksi dan efisiensi input (waktu) untuk aneka sayuran organik sebesar 25-50 persen.

4. Efisiensi biaya penggunaan BBM dapat mencapai Rp. 8,76 juta pertahun dari 2 buah kompor dari sebuah reaktor biogas.

5. Potensi implementasi sejumlah teknologi tepat guna berbasis bahan baku local di atas berdampak positif kepada peningkatan produksi / produktivitas aneka usaha tani ternak.

\section{SARAN}

1. Perlunya pendampingan lanjutan oleh PPl atau tenaga swadaya dari kelompok yang telah dilatih.

2. Teknologi berbasis bahan baku lokal ini sebaiknya direplikasi juga dihamparan lainnya sehingga selain peningkatan produktivitas usaha tani ternak meningkat, ramah lingkungan, dan produk pangan (aneka sayuran sehat) lebih tersedia/meningkat. 


\section{DAFTAR PUSTAKA}

Anonim. 2016. Program Penyuluhan Pertanian Tanaman Pangan, Perkebunan dan kehutanan Kec. Kupang Tengah.

Dato, T.O.D., dkk. 2014. Penerapan Teknologi IPAT-BO dalam Laporan IbW Sabu Raijua. Kerjasama Pemda Sabu Raijua dengan LPPM Undana, Politani dan Unkris Artha wacana Kupang.

Kune, P., Th. Mata Hine, dan Uli K. 2004. Pembudayaan Produksi dan Pemanfaatan Semen Cair Pejantan Unggul Guna Mengefektifan Kegiatan Inseminasi Buatan pada Sapi Bali dalam Meningkatkan Produktivitasnya. Buletin Perancangan dan Kaji Tindak. Edisi XV Bulan Juni 2004. Warta Pengabdian Kepada Masyarakat LPM Undana.

Ndoen, B. 2002. Aplikasi Teknologi Biogas pada Usaha Penggemukan Sapi. Makalah Program KKU Dirjen Dikti. 24 -26 Juli 2002. , 2010. Pengolahan limbah ternak menjadi bio - gas dan Pupuk Organik Padat dan cair .kegiatan penyuluhan di Desa oefafi kec. Kupang timur. Kab. Kupang.

Nono, O. H., J. Ly, 2000. Penerapan Teknologi Biogas Pada Usaha Ternak Babi Komersial. Laporan Vucer Program Dikti.

, Nono, P. Kune , B. Ndoen. 2011. IbM Kelompok Tani Ternak. Laporan penerapan IbM. LPM Undana

Wibowo, S. Murdinah, Y.N. Fawzya., 1988. Pedoman Mengelola Perusahaan Kecil. Penebar Swadaya. Jakarta 